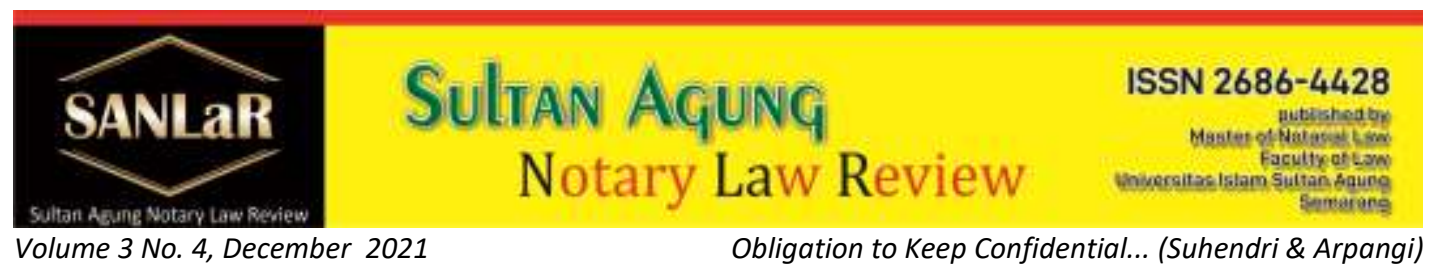

\title{
Obligation to Keep Confidential Notary Position in Criminal Jurisdiction Process Forgiven Rights \& Refuse Obligations
}

\author{
Suhendri*) and Arpangi**) \\ *) Faculty of Law, Universitas Islam Sultan Agung (UNISSULA) Semarang, E-mail: \\ hendrilns@gmail.com \\ ${ }^{* *}$ Faculty of Law, Universitas Islam Sultan Agung (UNISSULA) Semarang, E-mail: \\ arpangi@unissula.ac.id
}

\begin{abstract}
A notary occasionally receives false information from some parties, and then it becomes the basis of the making of authentic Notarial Deed. Notary criminal liability on the Notarial Deed based on false information should be analyzed and examined as well as its legal impacts. Based on the result of this research, it can be identified that a notary cannot be asked for his or her criminal liability related to the making of Notarial Deed based on false information from certain parties, and it cannot fulfill the formulation of counterfeiting criminal act in article 266 paragraph (1) jo. article 55 paragraph (1) of the Criminal Code. A notary can be asked for his or her criminal liability related to his or her Notarial Deed he or she made based on what he or she has seen, witnessed, or experienced in committing a criminal act on purpose, or Negligence; a notary makes a false Notarial Deed and he or she inflicts other parties. Referring to a criminal liability, a notary should fulfill the following elements; a criminal act, ability to be responsible for, committing an act on purpose or absence, and there is no reason for apology. A notary Notarial Deed based on false information does not automatically make the document itself invalid. The party who is inflicted by this document can propose a civil action to the Court of Justice in order to cancel the document. A notary criminal liability should be regulated in the next Notary Authority Act (UUJN).
\end{abstract}

Keywords: Criminal; Liability; Notary; Deed.

\section{Introduction}

Indonesia is a state of law. This is stated explicitly in Article 1 paragraph (3) of the 1945 Constitution (UUD 1945). A state of law is a state that runs its government system based on law (rechtstaat), not based on power (machstaat). 
The state is not omnipotent, the state cannot act arbitrarily. ${ }^{1}$ Power (state) without law has no authority, while law without (support) sanctions is difficult to enforce. In this relationship, the law legitimizes the state, while the state posits (creates, affirms, and enforces) and enforces the law. So, what characterizes the rule of law is the relationship between the state and law. The two are interrelated and complement each other.

Notary institutions are community institutions known as "notaries", which arise from the needs of the community who require evidence regarding the existing and/or existing civil legal relationship between them. Notary institutions and their servants are assigned by general authority (openbaar gezag), where and if the law requires it or is desired by the community, to make written evidence that has authentic power. ${ }^{2}$ Thus, the position of a notary was born because of the needs of the community, not a position that was deliberately created and then socialized to the general public ${ }^{3}$.

Notaries are public officials who have the duty and obligation to provide legal services and consultations to the public. Legal assistance that can be provided by a notary is in the form of making written evidence that has authentic power, namely in the form of an authentic deed or other authority as referred to in the law. ${ }^{4}$

Currently, the existence of a notary has been regulated in law, namely Law Number 30 of 2004 concerning Notary Positions, as amended by Law Number 2 of 2014 concerning Amendments to Law Number 30 of 2004 concerning Notary Positions (hereinafter referred to as UUJN). Law Number 30 of 2004 replaces the previous regulation, namely the Regulation of Notary Positions based on Stbl 1860-3 (Notary Regulation) which has been in effect in Indonesia for 244 years. This Notary Position Regulation is a substitute for Instructie voor Notarissen in Indonesia (Stbl 182211). In 1620, during the Republiek der Verenigde Nederlanden, the first notary in Indonesia, Melchior Kerchem, was appointed. ${ }^{5}$ Notary is a public official authorized to make authentic deeds and other authorities. The authority in question is the authority as stipulated in Article 15 of the UUJN. The position of a notary as a public official, in the sense that the authority that exists in a notary, is never given to other officials. As long as the

${ }^{1}$ Krisna Harahap, Konstitusi Republik Indonesia Menuju Perubahan ke-5, Grafiti Budi Utami, Bandung, 2009, p. 16.

${ }^{2}$ G.H.S. Lumban Tobing, Peraturan Jabatan Notaris, Erlangga, Jakarta, 1982, p. 2.

${ }^{3}$ A Chuasanga, Ong Argo Victoria. (2019). Legal Principles Under Criminal Law in Indonesia Dan Thailand, Jurnal Daulat Hukum, Vol 2, No 1 (2019) http://jurnal.unissula.ac.id/index.php/RH/article/view/4218

${ }^{4}$ Komar Andasasmita, Notaris Selayang Pandang, print. 2, Alumni, Bandung, 1983, p. 2.

${ }^{5}$ GHS Lumban Tobing, Op. Cit., p. 1-2. 
authority does not fall under the authority of other officials in making authentic deeds and other authorities, then the authority becomes the authority of a notary ${ }^{6}$.

Furthermore, Article 15 paragraph (3) of the UUJN states that in addition to the authority as referred to in paragraph (1) and paragraph (2), a notary has other powers as regulated in laws and regulations. So, in addition to the authority regulated in the UUJN, notaries also have the authority that is affirmed in other laws and regulations (outside the UUJN). In this case, the relevant laws and regulations emphasize that certain legal actions must be made with a notarial deed.

In accordance with the provisions of Article 15 UUJN, in addition to making an authentic deed, a notary also certifies and records letters made under the hand, namely letters made by individuals or by the parties on paper with sufficient stamp duty, by registering them in the register. A book made and provided specifically for it by a notary. In addition, the notary in his position is obliged to provide legal counseling and provide legal consultation to the public.

Authentic deeds as the strongest and most complete evidence, have an important role in every legal relationship in people's lives. In various business relationships, activities in the fields of banking, land, social activities, and others, it is necessary to have written evidence in the form of an authentic deed. ${ }^{7}$ This is in line with the growing demand for legal certainty in various economic and social relations, both at the regional, national and international levels. An authentic deed that clearly determines the rights and obligations of the parties will guarantee legal certainty and is also expected to avoid disputes. ${ }^{8}$

Notaries also have a role to provide legal advice in accordance with existing problems. Whatever legal advice is given by a notary to the parties and then poured into a deed, it remains as a wish or statement of the parties concerned, and not as a statement or statement of a notary. ${ }^{9}$

In practice, sometimes the parties or appearers provide information/statements that are not true (false) to the notary. The notary does not know that the

\footnotetext{
${ }^{6}$ Alam, Bahrul., \& Khisni, Akhmad. (2020). Legal Protection of Holders of Land Loss Data In The City Land Office of Kendari. JURNAL AKTA: Vol.7, No. 2, 159-164. Retrieved from http://jurnal.unissula.ac.id/index.php/akta/article/view/7963

${ }^{7}$ Article 1867 of the Civil Code states that written evidence is carried out in authentic writing or in writing under the hand.

${ }^{8}$ GHS Lumban Tobing, Op. Cit., p. 38-39.

${ }^{9} \mathrm{Habib}$ Adjie, Hukum Notaris Indonesia (Tafsir Tematik Terhadap UU No. 30 Tahun 2004 Tentang Jabatan Notaris), first print., Refika Aditama, Bandung, 2009, p. 24.
} 
statement is a false statement. The notary shall pour the information/statement in the form of a notarial deed. Furthermore, other parties who feel aggrieved take issue with the notary deed, even reporting the notary to law enforcement officials on the basis of committing a crime. In such a case, the problem that arises is, can a notary be held accountable under criminal law?

If a notary commits a crime, then of course he can be held accountable under criminal law. This is in line with Hans Kelsen's view that the concept related to legal obligations is the concept of legal responsibility, namely a person is legally responsible for a certain act or the person bears legal responsibility. ${ }^{10}$ The problem related to the duties of a notary is the making of a notarial deed based on a false statement. The main question is, can a notary be held criminally responsible for making a deed based on false information? Related to this problem, UUJN does not regulate criminal acts related to the position of a notary. Thus, if there is a criminal act related to the duties of a notary, the provisions of the Criminal Code will be applied.

\section{Research Methods}

In writing this thesis, we use a directed method in order to provide systematic thinking in an effort to test the scientific truth we face. The research method is the process of finding legal issues and being able to achieve the desired goals and will give birth to provide a prescription for the answers to the problems faced so that scientific research can be accounted for. In connection with this, in order to create a scientific work that is systematic, logical and directed to produce new ideas, arguments, theories or concepts in accordance with the times.

Because the type of research used is normative juridical research, the problem approach and data collection methods used are: a) Problem Approach, using a statutory approach, a conceptual approach, and a historical approach; b) Legal Research, writing using a normative juridical and empirical juridical research approach; c) Sources of Legal Materials, using Primary Legal Materials, Secondary Legal Materials, Analysis of Legal Materials; and d) Interviews, data collection by means of interviews conducted face to face directly with data sources ${ }^{11}$.

\footnotetext{
${ }^{10}$ Kelsen, Hans, General Theory Of Law and State, Teori Umum Hukum Dan Negara, Dasar-Dasar IImu Hukum Normatif Sebagai IImu Hukum Deskriptif-Empirik, translated by Soemardi, BEE Media Indonesia, Jakarta, 2007, p. 81.

${ }^{11}$ Arrohim, Mohammad B., \& Wahyuningsih, Sri Endah. (2020). Analysis of Judicial Application of Criminal Penalty Against Notary / Land Deed Officials Conducting Making Crime of the Fake 


\section{Result and Discussion}

\subsection{The Basis for Granting the Right of Denial to the Position of a Notary}

The notary is obliged to keep the contents of the deed and all information obtained in the execution of his office confidential. This is in line with the oath of office pronounced before the Notary carries out his office, as confirmed in Article 4 paragraph (2) of the UUJN. Notaries cannot freely disclose or divulge the secrets of their positions to anyone unless there are other laws and regulations that allow them to disclose the secrets of their positions, unless the law provides otherwise.

This obligation becomes a renegade obligation attached to the duties of his position. A Notary is considered as an official where someone can get reliable advice, and everything written and stipulated is correct, as a strong document maker in the legal process. The relationship that exists between a Notary and his client occurs when the client comes to the Notary asking that his actions or deeds be formulated into an authentic deed in accordance with his authority. Then, the Notary makes the deed according to the request or the will of the client. The purpose of making an authentic deed is solely so that the deed can be used as strong evidence if one day there is a dispute between the parties or there is a lawsuit from another party. This is because the authentic deed has the power of outward proof ${ }^{12}$.

The purpose of the Notary being granted the right of refusal based on Article 170 of the Criminal Procedure Code is to protect the confidentiality of the position. But in fact, this right of denial does not mean anything when dealing with the interests of the judicial process. This is because in the Law on Notary Positions, especially in Article 4 paragraph (2) and Article 16 paragraph (1) letter f, it does not provide clarity regarding the obligation to deny the Notary. The presence of a Notary has an important role in legal traffic, especially with regard to the manufacture of authentic written evidence. This aims to ensure legal certainty, order and legal protection needed by the community regarding written evidence that has an authentic nature regarding legal circumstances, events, or actions as mandated in Article 1868 of the Civil Code. This obligation to deny can end when there are laws and regulations that instruct the Notary to disclose the secret of his position. Even so, the Notary's obligations can still be kept secret by using the right of denial (verschoningsrecht) granted to him based on the provisions of

Authentic Deed in State Court of Semarang. JURNAL AKTA: Vol.7, No. 2, 183-188. Retrieved from http://jurnal.unissula.ac.id/index.php/akta/article/view/7891

${ }^{12}$ Deen, Thaufiq., Ong Argo Victoria \& Sumain. (2018). Public Notary Services In Malaysia. JURNAL AKTA: Vol. 5, No. 4, 1017-1026. Retrieved from http://jurnal.unissula.ac.id/index.php/akta/article/view/4135 
Article 1909 paragraph (2) point 3e of the Civil Code and Article 170 paragraph (1) of the Criminal Procedure Code.

\subsection{Rights and Obligations and Notary Criminal Liability of Notary Due to False Information on the Deed Made}

A notary may be involved in criminal liability and may be held criminally responsible if he fulfills the elements prohibited by law. The existence of the ability to be responsible for the maker, the inner connection between the maker and his actions in the form of intentional (dolus) or negligence (culpa) and no reason for eliminating mistakes or no excuses for forgiveness.

Regarding the criminal liability of a notary, the question that arises is, in what case can a notary be held criminally responsible if he makes a deed based on false information? The answer to this question, of course, must refer to the applicable regulations. Referring to the applicable regulations, it is known that a notary can be held criminally responsible in the case of making a deed based on false information, and the rules related to the above problems are Article 263 paragraph (1), 1st 264 paragraph (1), or 266 paragraph (1) of the Criminal Code jo. Article 55 paragraph (1) of the Criminal Code. While the provisions of the UUJN do not regulate criminal acts committed by a notary.

Furthermore, the author observes and analyzes, in the deed of parties (Partijn akten) where this deed is a deed made before a notary in which case the notary pours into an authentic deed all wishes or desires based on the agreement of the parties in the form of statements, agreements or stipulations, that if a notary is declared as "a person who participates in ordering to enter false information into an authentic deed ...", then an act of entering such false information must have an intentional mental connection with the criminal act committed and consciously cooperate with the parties who were carried out physically to carry out the crime. If it is stated that the notary has ordered to enter false information into the deed he has made, what are the interests and benefits for the notary. Therefore, this is something that is impossible for a notary to do, which if done, it is the same as harming himself, destroying his own profession and life. Then is it possible that the parties who appear before the notary to order to make an authentic deed, will want to be ordered by the notary to place false information in the deed made before the notary, even if it is their mutual agreement which is the will of the parties, and the notary is only in charge of pouring or entering a statement and agreement that has been agreed upon by the parties in the form of an authentic deed. So in this case the notary cannot be said to be a father or perpetrator. will want to be ordered by a notary to place a false statement in the deed made before a notary, even if it is their mutual agreement which is the will of the parties, and the notary is only in charge of pouring or entering a statement/information and agreement that has been agreed upon by the parties 
into the document, authentic deed form. So in this case the notary cannot be said to be a father or perpetrator. ${ }^{13}$

Based on the Law on Notary Positions Number 30 of 2004, it regulates the authority of the MPD, in this case regarding the approval of the summons of a Notary, if there is a summons for a Notary, then the MPD will study the summons, whether in the making of the Deed an error was found in the procedure for making the Deed, namely the making of the Deed. An error has been found from the external, formal or material aspects, if in the making of the Deed no errors are found from the external, formal or material aspects, then the MPD has the authority not to give approval for summons to a Notary.

The procedures for implementing the summons of a Notary by Investigators are related to the Law on Notary Positions Number 30 of 2004 as follows: ${ }^{14}$

a. The investigator submits a letter to the Regional Supervisory Council (MPD) stating for what purposes, whether to take a photocopy of the Minutes of Deed and/or the letters attached to the Minutes of Deed or the Notary Protocol in the Notary's depository; or the need to summon a Notary to attend an examination related to the Minutes of Deed he made or the Notary Protocol that is in the Notary's custody.

b. The petition briefly explains what the case is and who the suspect is.

c. After obtaining approval, the investigator can take action by the police, namely receiving reports or complaints.

After the issuance of the new Notary Position Law but based on Article 66 paragraph I of Law Number 2 of 2014 concerning the current Notary Position, the authority to summon a Notary in the old UUJN is with the MPD and after the issuance of the new UUJN, the authority to summon a Notary is there at the Honorary Council

A summons made by an investigator is considered valid if the investigator clearly states the reason for the summons, and the summons is a legally responsible action, that is, it is not against the law, is in line with legal obligations, is appropriate, makes sense within the investigator's office, based on proper considerations and respect human rights. The MKN party is obliged to provide an answer that is approved or rejected within 30 (thirty) working days, if this time is exceeded then the MKN is considered to have received the request for approval from the investigator.

\footnotetext{
${ }^{13} \mathrm{http}: / /$ medianotaris.com/pertanggungjawaban_notaris_atas_keterangan_palsu_oleh_para_pih ak_berita700.html, accessed on 11 February $202 \overline{1}$ at 10.00 WIB.

${ }^{14}$ Interview with IPDA Deni Arisandy, SH, Head of Subunit I Harda Polresta Cirebon, April 6, 2021
} 


\subsection{Legal Protection Regarding the Rights and Obligations of Notary Disobeys in a Crime of Counterfeiting}

The assessment of the notarial deed must be carried out on the basis of a valid presumption (presumptio iustae causa). This principle can be used to evaluate a notarial deed, i.e. a notarial deed must be considered valid until a party declares that the deed is invalid. To declare or judge that the deed is invalid, you must file a lawsuit to the District Court. As long as and as long as the lawsuit continues until there is a court decision that has permanent legal force, the notarial deed remains valid and binding on the parties or anyone with an interest in the deed..$^{15}$ Applying the principle of legal presumption for a notary deed, then the provisions contained in Article 84 of the UUJN, namely the deed in question only has the power of proof as an underhand deed is no longer needed, so that the cancellation of the notary deed can only be canceled or null and void by law. The legality of a notarial deed relating to a deed that can be canceled is an act containing defects, namely the notary's authority to make a deed outwardly, formally, and materially, and not in accordance with the legal rules regarding the making of a notary deed. This principle cannot be used to assess the notarial deed is null and void, because the null and void deed is considered to have never been made. ${ }^{16}$

Thus, for certain reasons as stated above, the position of the notary deed is: ${ }^{17}$

a. Can be cancelled;

b. Null and void;

c. Have the power of proof as a deed under the hand;

d. Canceled by the parties themselves; and

e. Canceled by a court decision that has permanent legal force due to the application of the principle of legal presumption.

A notary may be free from responsibility and legal liability due to a defective deed, as long as the legal defect is caused by the fault of another party, or a statement or letter evidence submitted by the client. Recognize forms of legal defects that are not the fault of a notary, for example the existence of asphalt or original but fake identities, such as Identity Cards, Family Cards, Passports, Certificates of Heirs, Certificates, Agreements, Decision Letters, BPKB, Marriage Certificates, Birth Certificates and etc. These documents are generally used as a reference for notaries in serving the public as public officials assigned to represent the state in making authentic deeds. ${ }^{18}$

\footnotetext{
${ }^{15}$ Habib Adjie, Op. Cit., p. 140.

${ }^{16}$ Ibid., p. 141.

17 Ibid

${ }^{18}$ Sjaifurrachman and Habib Adjie, Aspek Pertanggungjawaban Notaris dalam Pembuatan Akta, Mandar Maju, Bandung, 2011, p. 26.
} 
The problem is what if the documents which incidentally are legal products of state institutions can be easily falsified. Obviously this is very detrimental to many parties, including the notary profession. The easier it is for the document to be falsified, the more likely it is that the notary will be dragged into a legal case, because the notary only bases the making of the deed on the truth of the document or the formal truth, while the material truth rests with the parties and the legal product brought before the notary. If the information submitted to the notary is fake or the documents given to the notary are fake, then the deed and binding made before the notary do not mean that it is fake. What is submitted to the notary contains the truth, while the facts of lies conveyed by the appearers are not the authority and not the responsibility of the notary, because the notarial deed does not guarantee that the parties are telling the truth, but what is guaranteed by the notary deed is that the parties correctly say as contained in their deed of agreement, so that if there is a problem in the material aspect should be investigated first against the parties who deliberately provide false documents to the notary, and not vice versa the notary who is blamed. In fact, the legal process does not only stop at this stage, notaries are generally also accused of colluding with the parties to issue a fake notarial deed, but what is guaranteed by the notary deed is that the parties are right in saying as contained in their deed of agreement, so that if there is a problem in the material aspect, an investigation should be carried out first against the parties who intentionally provide false documents to the notary, and not the notary who is to blame. In fact, the legal process does not only stop at this stage, notaries are generally also accused of colluding with the parties to issue a fake notarial deed.

As it is known that the material aspect of a notarial deed is certainty about the material of a deed, namely what is stated in the deed is valid evidence against the parties who made the deed or parties who have rights and applies to the public. Information or statements contained in the official deed or statements of the parties given or submitted before a notary must have an element of truth in what is stated in the deed. If the information/statements of the presenters are not true, then it is the responsibility of the parties themselves. Thus, the contents of the notary deed have certainty as legal evidence for or between the parties, the heirs, and the recipients of the rights.

Information or statements of the parties submitted before a notary are the basic material for a notary to make a deed according to the wishes of the parties who appear before a notary. Without the information or statements and wishes of the parties, it is impossible for a notary to make a deed. If there is information or a statement that is allegedly false that is included in the notarial deed, it does not cause the deed to be false. For example, a notary entering information into a notary deed based on a false identity letter (for example a fake ID card), does not mean that the notary enters false information into the notary deed, as referred to in Article 264 paragraph (1) and Article 266 paragraph (1) of the Criminal Code. 
Materially, the falsity of this matter is the responsibility of the parties concerned, unless the notary is aware of the falsity.

The problem is, what is the position of the notary deed based on the false statement or statement? According to Habib Adjie, the imposition of a crime against a notary does not necessarily cause the deed to be made null and void by law. One thing that is not legally correct is if there is a criminal court decision with a decision to cancel the notary deed, on the grounds that the notary is proven to have committed a criminal act of forgery. Thus, the thing that must be done by the parties who will place a notary as a convict, for the deed made by or before the notary concerned, is to file a civil lawsuit to request the cancellation of the deed. ${ }^{19}$

But in fact, many problems that arise are in terms of the application of the procedural law used when a dispute occurs between the parties in the Deed, and the Deed is used as evidence. For this purpose, Article 1866 of the Civil Code mentions several kinds of evidence which are as follows: writings/letters, witnesses, allegations, confessions and oaths. Meanwhile, the provisions governing the order in which evidence is mentioned in Article 184 paragraph (1) of the Criminal Procedure Code state that valid evidence is witness testimony, expert testimony, letters, instructions, and statements from the defendant. This has resulted in a disagreement between the Notary/Supervisory Council and law enforcers in the enforcement of the procedural law for alleged violations. In civil law,

Based on the description above, it is known that a notarial deed based on false information does not automatically result in the deed being null and void. The parties who are harmed by the existence of such a deed must file a civil lawsuit to the court to cancel the deed. The deed will be void if it has been decided by the court and the decision is a decision that has permanent legal force.

The need to regulate the criminal liability of a notary in the UUJN is also based on the consideration that the imposition of criminal sanctions against a notary can be carried out as long as the limitations as stated above, meet the formulation of violations in the UUJN, and of course the Criminal Code as lex generalis. If the notary's action fulfills the formulation of a criminal act, but according to the UUJN it is not a violation, then the notary concerned cannot be held criminally responsible, because the measure to assess a notary deed must be based on the UUJN.

\section{Closing}

There is a basis for granting the right to deny the position of a notary, because it is related to the task in carrying out his position regarding his authority in making

${ }^{19}$ Ibid., p. 29 
an authentic deed, which in his authority in making the authentic deed lies the interests of the parties who appear before the notary to be poured into an authentic deed, therefore the interests of the parties contained in the deed must be kept confidential by the position of the notary, so that the notary has an obligation to keep the contents of the deed secret along with the information he obtained in the making of the deed, therefore the notary is given a rights attached to his position called the right of denial. Notaries cannot be held criminally responsible for making a party deed (partijn akten) based on false information, and cannot fulfill the formulation of the element of the crime of forgery in Article 266 paragraph (1) in conjunction with Article 55 paragraph (1) of the Criminal Code. However, the notary can be held criminally responsible for the relaas deed or official deed (ambtelijke akten) if the notary intentionally or negligently makes a fake deed, thereby harming other parties. The notarial deed made based on false information does not automatically result in the deed being null and void. The parties who are harmed by the existence of such a deed must file a civil lawsuit to the court to cancel the deed. The deed will be void if it has been decided by the court and the decision is a decision that has permanent legal force.

\section{References}

Journals:

[1] A Chuasanga, Ong Argo Victoria. (2019). Legal Principles Under Criminal Law in Indonesia Dan Thailand, Jurnal Daulat Hukum, Vol 2, No

1

(2019)

http://jurnal.unissula.ac.id/index.php/RH/article/view/4218

[2] Alam, Bahrul., \& Khisni, Akhmad. (2020). Legal Protection of Holders of Land Loss Data In The City Land Office of Kendari. JURNAL AKTA: Vol.7, No. 2, 159-164. Retrieved from http://jurnal.unissula.ac.id/index.php/akta/article/view/7963

[3] Arrohim, Mohammad B., \& Wahyuningsih, Sri Endah. (2020). Analysis of Judicial Application of Criminal Penalty Against Notary / Land Deed Officials Conducting Making Crime of the Fake Authentic Deed in State Court of Semarang. JURNAL AKTA: Vol.7, No. 2, 183188. Retrieved

from http://jurnal.unissula.ac.id/index.php/akta/article/view/7891

[4] Deen, Thaufiq., Ong Argo Victoria \& Sumain. (2018). Public Notary Services In Malaysia. JURNAL AKTA: Vol. 5, No. 4, 1017-1026. Retrieved from http://jurnal.unissula.ac.id/index.php/akta/article/view/4135 
[5] Ong Argo Victoria, (2018) Waqf Al-Nuqūd In Indonesia (In Law Perspective), Jurnal Pembaharuan Hukum Vol 5, No 1 Universitas Sultan

Agung,

http://jurnal.unissula.ac.id/index.php/PH/article/view/2999

[6] Sukarmi, S., \& Victoria, A. (2018). Cash Waqf in Sustaining Of Indonesian Society "In Legal \&amp; Economic Perspective". ALITQAN: JOURNAL OF ISLAMIC SCIENCES AND COMPARATIVE STUDIES, 2(1), 83-97. https://doi.org/10.31436/al-itqan.v2i1.43

Books:

[1] G.H.S. Lumban Tobing, Peraturan Jabatan Notaris, Erlangga, Jakarta, 1982.

[2] Habib Adjie, Hukum Notaris Indonesia (Tafsir Tematik Terhadap UU No. 30 Tahun 2004 Tentang Jabatan Notaris), First Print., Refika Aditama, Bandung, 2009.

[3] Kelsen, Hans, General Theory Of Law and State, Teori Umum Hukum Dan Negara, Dasar-Dasar IImu Hukum Normatif Sebagai Ilmu Hukum Deskriptif-Empirik, translated by Soemardi, BEE Media Indonesia, Jakarta, 2007.

[4]

Komar Andasasmita, Notaris Selayang Pandang, print.2, Alumni, Bandung, 1983.

[5] Krisna Harahap, Konstitusi Republik Indonesia Menuju Perubahan ke-5, Grafiti Budi Utami, Bandung, 2009.

[6] Sjaifurrachman dan Habib Adjie, Aspek Pertanggungjawaban Notaris dalam Pembuatan Akta, Mandar Maju, Bandung, 2011.

Internet:

http://medianotaris.com/pertanggungjawaban_notaris_atas_keterangan _palsu_oleh_para_pihak_berita700.html, accessed on 11 February 2021 at 10.00 WIB.

Interview:

Interview with IPDA Deni Arisandy, S.H, Kasubnit I Harda Polresta Cirebon, on 6 April 2021 